\title{
Variant angina in a patient with non-obstructive atherosclerotic coronary lesion and myocardial bridging: a puzzle not so easy to solve
}

\section{Željko Baričević*, Kristina Marić Bešić, Maja Strozzi}

University of Zagreb School of Medicine, University Hospital Centre Zagreb, Zagreb, Croatia
RECEIVED:

February 7, 2016

ACCEPTED:

February 20, 2016

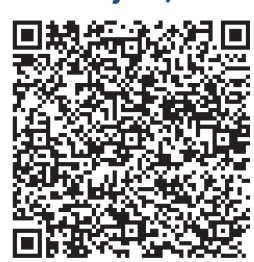

KEYWORDS: coronary artery spasm, variant angina, myocardial bridging, acute coronary syndrome. CITATION: Cardiol Croat. 2016;11(3-4):93-94. | DoI: http://dx.doi.org/10.15836/ccar2016.93

*ADDRESS FOR CORRESPONDENCE: Željko Baričević, Klinički bolnički centar Zagreb, Kišpatićeva 12, HR-10000 Zagreb, Croatia. / Phone: +385-1-2367-466 / E-mail: zbaricev@gmail.com

ORCID: Željko Baričević, http://orcid.org/0000-0002-5420-2324 • Kristina Marić Bešić, http://orcid.org/0000-0002-4004-7271 Maja Strozzi, http://orcid.org/0000-0003-4596-8261

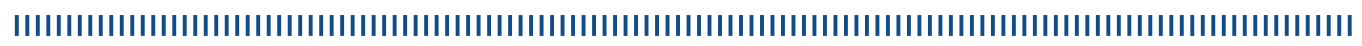

Case presentation: A 66-year-old man was admitted to our department due to persistent chest pain that awoke him from sleep, accompanied by transient ST elevation in anteroseptal leads (Figure 1). Several months earlier a coronary angiography was done due to anginal pain that only revealed nonsignificant atherosclerotic lesion in the ostial segment of the left anterior descending (LAD) artery and mild myocardial bridging of the middle LAD segment, and the patient was discharged on low dose of bisoprolol, amlodipine, aspirin, statin and sublingual nitroglycerin as needed. At this point, the pain was relieved after administration of sublingual nitroglycerin. Echocardiogram showed no regional wall abnormalities and the high-sensitive troponin $\mathrm{T}$ test came back normal repeatedly. Coronary angiography was performed the following day, showing nonstenotic coronary lesions at first, but after several contrast dye injections, the ostial LAD showed a total occlusion (Figure 2). Intracoronary nitroglycerin was then given that gradually led to a complete relief of the obstruction, revealing the underlying atherosclerotic lesion (Figure 3).

Conclusion: Based on previous findings, the diagnosis of variant („Vasospastic") angina was made ${ }^{1}$. The patient was discharged with diltiazem and long-lasting nitrate. Beta blockade can be useful in case of effort-induced angina caused by atherosclerotic disease and myocardial bridging. However, we decided to withhold it because of possible occurrence of the unopposed alpha-receptor mediated coronary vasoconstriction. We believe that the coronary artery spasm (CAS) prevention was the primary treatment goal in this case, since there were no signs of effort-induced ischemia on the treadmill and myocardial SPECT test. Abstinence from cigarette smoking and optimal dosing and timing of calcium antagonists remain the cornerstone of CAS therapy ${ }^{2}$. These patients with acute coronary syndrome (ACS) without culprit lesion have an excellent prognosis for survival and coronary events after 3 years

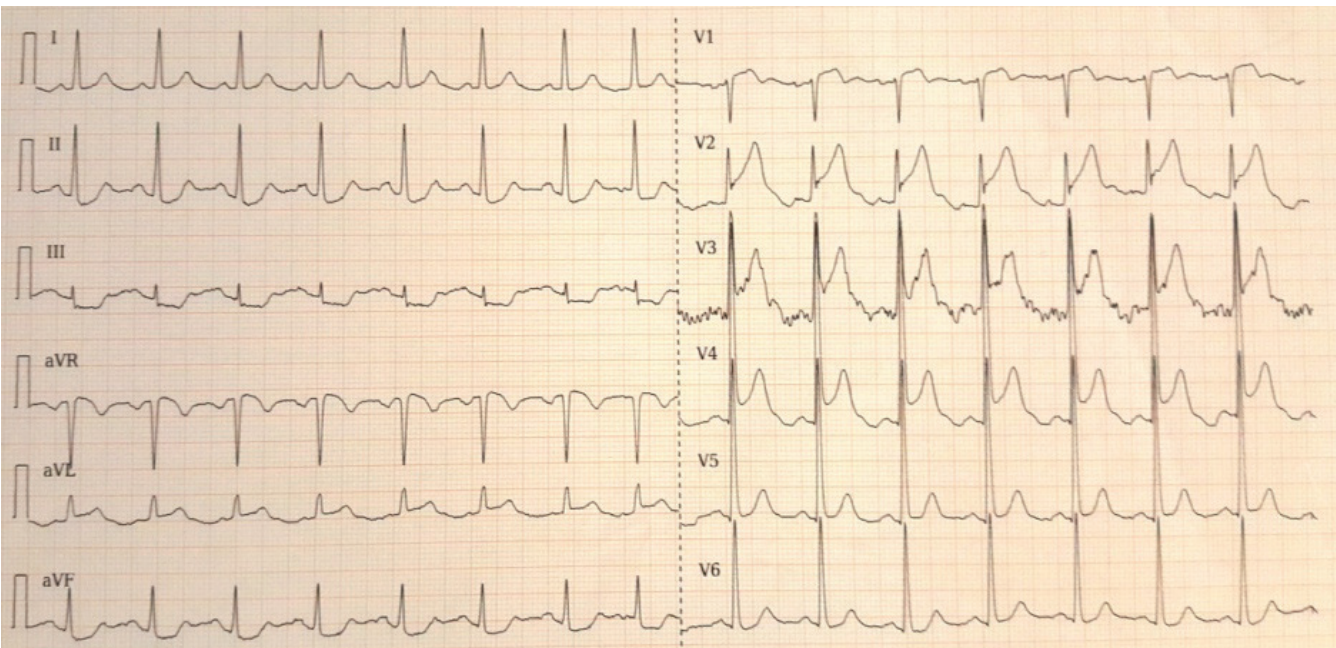

FIGURE 1. 12-lead electrocardiogram during pain crisis. 
compared with patients with obstructive $\mathrm{ACS}^{3}$. However, the case of persistent angina represents a challenging problem and leads to an open question whether there is a role of stenting non-severe proximal stenotic lesions which may possibly predispose to local vasospasm.
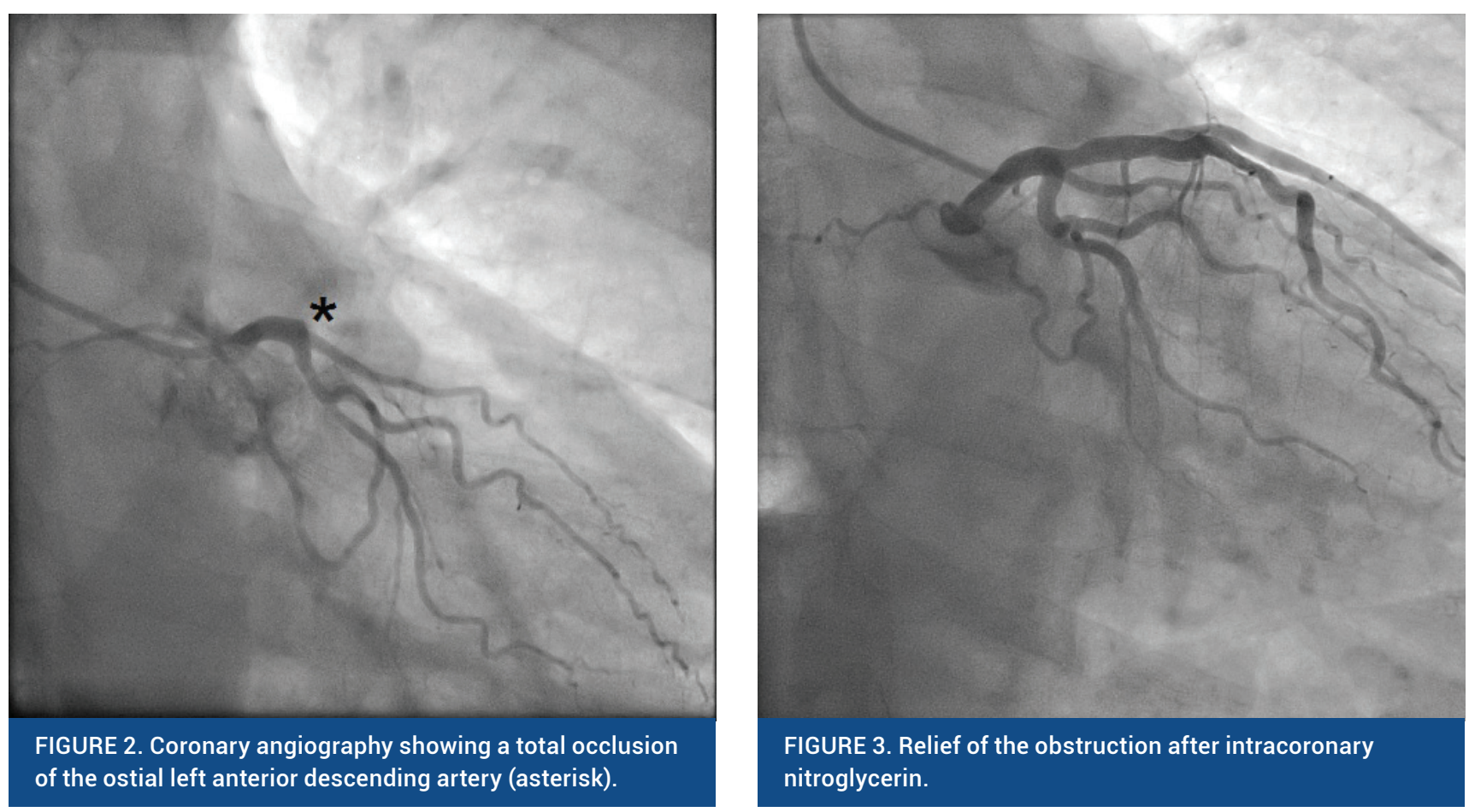

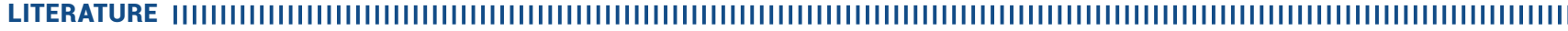

1. Prinzmetal M, Kennamer R, Merliss R, Wada T, Bor N. Angina pectoris. I. A variant form of angina pectoris; preliminary report. Am J Med. 1959;27:375-88. DOI: http://dx.doi.org/10.1016/0002-9343(59)90003-8

2. Hung MJ, Hu P, Hung MY. Coronary artery spasm: review and update. Int J Med Sci. 2014;11(11):1161-71. DOI: http://dx.doi.org/10.7150/ijms.9623

3. Ong P, Athanasiadis A, Borgulya G, Voehringer M, Sechtem U. 3-year follow-up of patients with coronary artery spasm as cause of acute coronary syndrome: the CASPAR (coronary artery spasm in patients with acute coronary syndrome) study follow-up. J Am Coll Cardiol. 2011;57:147-52. Dol: http://dx.doi.org/10.1016/j.jacc.2010.08.626 